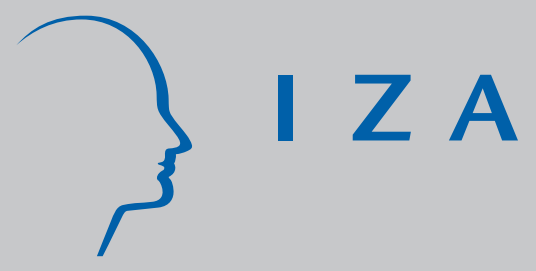

IZA DP No. 1353

Do Pensions Impede Phased Retirement?

William E. Even

David A. Macpherson

October 2004 


\title{
Do Pensions Impede Phased Retirement?
}

\author{
William E. Even \\ Miami University and IZA Bonn \\ David A. Macpherson \\ Florida State University and IZA Bonn
}

\section{Discussion Paper No. 1353 \\ October 2004}

\author{
IZA \\ P.O. Box 7240 \\ 53072 Bonn \\ Germany \\ Phone: +49-228-3894-0 \\ Fax: +49-228-3894-180 \\ Email: iza@iza.org
}

\begin{abstract}
Any opinions expressed here are those of the author(s) and not those of the institute. Research disseminated by IZA may include views on policy, but the institute itself takes no institutional policy positions.
\end{abstract}

The Institute for the Study of Labor (IZA) in Bonn is a local and virtual international research center and a place of communication between science, politics and business. IZA is an independent nonprofit company supported by Deutsche Post World Net. The center is associated with the University of Bonn and offers a stimulating research environment through its research networks, research support, and visitors and doctoral programs. IZA engages in (i) original and internationally competitive research in all fields of labor economics, (ii) development of policy concepts, and (iii) dissemination of research results and concepts to the interested public.

IZA Discussion Papers often represent preliminary work and are circulated to encourage discussion. Citation of such a paper should account for its provisional character. A revised version may be available directly from the author. 
IZA Discussion Paper No. 1353

October 2004

\section{ABSTRACT}

\section{Do Pensions Impede Phased Retirement?}

Many workers reveal a preference for a gradual reduction in work hours as they approach retirement ("phased retirement"), rather than a sudden change from full-time work to full-time retirement. Pension regulations may impede phased retirement without a switch of employers by prohibiting access to pension assets. This study uses Health and Retirement Survey data to investigate the extent to which a gradual reduction in work hours is made difficult by pensions, particularly defined benefit plans. The study also explores other possible impediments to phased retirement.

JEL Classification: J26, J32

Keywords: phased retirement

Corresponding author:

David A. Macpherson

Department of Economics

Florida State University

Tallahassee, Florida 32306

USA

Email: dmacpher@mailer.fsu.edu 


\section{Introduction.}

The transition into retirement is frequently thought of as a one-time event where a worker switches from full-time employment to full-time retirement. However, many workers gradually reduce work hours as they make the transition into retirement. This process of "phased retirement" may involve a switch of employers, a switch to self-employment, or a change of career.

Some legislators are concerned that pensions impede phased retirement without a switch of employers. As a result, the Phased Retirement Liberalization Act was proposed in 2000. If adopted, the legislation would allow pension payments to be made, even without a termination of employment, after the earlier of (a) the normal retirement age defined in defined benefit (DB) pensions; (b) age 59-1/2; or (c) 30 years of service. ${ }^{1}$ The basic premise behind the legislation is that if workers could access their pension assets without changing employers, fewer would have to switch employers in order to begin a gradual reduction in their work effort.

This paper investigates the claim that the current legislative restrictions on access to pension wealth impede phased retirement and cause workers to unnecessarily switch employers as they phase into retirement. Section 2 provides a brief review of existing literature on phased retirement and a description of the pension regulations that could hamper a worker's desire to pursue a phased retirement strategy. Section 3 uses data from the Health and Retirement Study (HRS) to examine the frequency of phased retirement and how it interacts with pension coverage and job-switching. The multivariate analysis in section 4 illustrates that pension coverage reduces the chance that a worker pursues a phased retirement strategy, but increases the chance 
that a worker switches jobs to accommodate such desires. Evidence presented in section 5 suggests that switching jobs to pursue a phased retirement strategy can be quite costly in terms of earnings losses.

\section{Background.}

Several studies illustrate that the transition into retirement frequently involves a spell of part-time work or a switch of employers. Some of the earliest work on the subject was by Gustman and Steinmeier (1984), Honig (1985), and Honig and Hanoch (1985). Using data from the 1960 s and early 1970 s, these studies illustrated that "partial" retirement was a fairly common phenomenon and often involved a switch of employers. More recently, Ruhm (1990) found that more than 60 percent of workers do not retire directly from their "career" job and over one-half had a spell of partial retirement. ${ }^{2}$ Also, less than 10 percent of workers partially retire without first leaving their career job. Quinn (2000) estimates that at least one-third of men and one-half of women accept a bridge job between their last "career job" and complete labor force withdrawal. ${ }^{3}$ The study also finds that many older Americans retire gradually, often using parttime jobs, bridge jobs, or stints of self-employment on the path to retirement. ${ }^{4}$

The fact that many workers switch to part-time work as they make the transition into retirement is consistent with stated worker preferences. In a recent survey of workers

\footnotetext{
${ }^{1}$ Under a DB plan, a worker is promised a retirement benefit that is usually based on a worker's salary history and years of service.

${ }^{2}$ Ruhm defines a career job as the longest spell of employment with a single firm, up to and including the job held at the start of the RHLS.

${ }^{3}$ Quinn defines a career job as a job that lasts at least 10 years in which the employee works at least 1600 hours per year.

${ }^{4}$ Some of the earliest work on the issue of partial retirement is Gustman and Steinmeier (1984) and Honig (1984, 1985). These studies examine retirement behavior in the 1960s and early 1970s.
} 
approaching retirement, nearly three-fourths report that they would prefer to reduce their work hours gradually rather than retire abruptly [Graig and Pagenelli (2000)]. What is somewhat surprising, however, is evidence that most workers switch jobs to accommodate a reduction in work hours. A switch of employers means that workers will incur search costs and may realize a wage cut if they have job-specific skills. In fact, Ruhm (1990) finds that a significant share of workers who switch jobs as they approach retirement experience more than a 25 percent cut in earnings and the earnings losses are especially pronounced for workers who simultaneously change occupation and/or industry.

The reasons that employees switch employers to accommodate their preference for reduced work hours can be divided into two broad categories. First, employers may be unwilling to allow their workers to switch to part-time work. Second, workers may prefer to switch employers as they reduce hours, even though the employer may have allowed a switch to part-time work.

There are several factors that may cause an employer to prefer full-time over part-time workers. First, quasi-fixed labor costs which depend on the number of workers and not the number of hours per worker could drive up the cost of part-time labor relative to that for fulltime labor. ${ }^{5}$ Examples of quasi-fixed costs include fringe benefits that have a fixed cost per worker and training costs. Consistent with theory, there is empirical evidence that training costs and some fringe benefits reduce the fraction of workers who are employed part-time. ${ }^{6}$

A firm's production technology may also make employers prefer full-time workers. For example, some production processes require team effort in which coordination of work across employees is important. If the absence of one member of the team reduces productivity

\footnotetext{
${ }^{5}$ Oi (1962) provides the seminal work on the role of quasi-fixed labor costs on labor market outcomes.
} 
substantially, part-time employees would be detrimental to productivity. Alternatively, some production processes have peak load problems that could be ameliorated with the use of parttime employees (e.g. retail establishments). Finally, if a job requires a substantial amount of capital per worker, firms may be reluctant to allow part-time work since it may result in expensive capital remaining idle.

While quasi-fixed costs or production technologies may cause employers to prefer a single full-time worker over two half-time workers at the same hourly wage rate, if employees are willing to take a sufficient reduction in the hourly wage in order to have a part-time work schedule, the employer could be made indifferent between part-time and full-time workers. However, the greater the wage reduction necessary for the employer to agree to a part-time schedule, the less likely part-time work will be agreeable to both parties. In fact, it is quite possible that the wage reduction necessary to make the employer indifferent between a part-time and full-time worker exceeds the wage cut that a worker would realize with a switch of employers.

Consistent with the premise that employer willingness to offer part-time work to employees varies across jobs are the large inter-industry differences in the fraction of workers with part-time jobs (Fallick 1999). For example, in retail trade, 40 percent of workers are parttime employees; in mining, only 10 percent are part-time. Also, Watson-Wyatt (2000) finds that the availability of phased retirement programs allowing workers to reduce work varies dramatically across industry and is most prevalent in the educational sector. The study suggests that phased retirement would be relatively easy in a college or university environment where a

\footnotetext{
${ }^{6}$ See, for example, Montgomery and Cosgrove (1993).
} 
professor could teach every other semester whereas it might be costly to accommodate such schedules in other jobs. ${ }^{7}$

Even when employers are willing to allow workers to reduce hours, employees may choose to switch jobs as they reduce work hours for several reasons. First, an employee may wish to switch jobs to acquire a job with fewer fixed time or money costs. An example of a fixed time cost would be time spent traveling to and from work. If a worker cuts from 8 to 4 hour days, the time cost of travel would be unaffected. An example of a fixed money cost of working would be the cost of clothing required for the job.

Restricted access to pension assets is a second reason that employees may choose to switch jobs as they phase into retirement. Several articles discuss pension regulations that could discourage phased retirement by limiting access to pension wealth. ${ }^{8}$ First, if a worker is included in a DB plan that calculates benefits on the participant's final average pay, switching to part-time work may have severe consequences for the worker's eventual retirement benefits. ${ }^{9}$ Second, in defined contribution (DC) plans, tax law prohibits penalty-free distributions until age $59 \frac{1}{2}$ unless taken as an annuity, as payments for an expected lifetime, or in the case of death or disability and workers may have to terminate service with their employer to access pension assets even if they are over age $591 / 2 .^{10}$ Profit sharing and stock bonus plans are allowed to give in-service distributions, but not all do. In-service distributions are prohibited in money purchase plans. Fourth, current regulations do not allow payment of DB pension benefits prior

\footnotetext{
${ }^{7}$ Allen, Clark, and Ghent examine the consequences of a phased retirement program introduced at the University of North Carolina system. One of their key findings is that lower performers are those most likely to go into phased retirement.

${ }^{8}$ See, for example, Working Group Report (2000), Fields and Hutchens (2002) and Purcell (2004). Latulippe and Turner (2000) provide a cross-country comparison of regulations that could influence phased retirement.

${ }^{9}$ There is, however, substantial uncertainty over the legality of reducing benefits when a worker's final average pay declines.
} 
to a participant's normal retirement age unless there is a complete severance from employment with the plan sponsor. Since wealth accrual in DB plans can drop off substantially after eligibility for early or normal retirement benefits, some workers may find it beneficial to switch employers without any desire to reduce hours merely to maximize the value of their pension. ${ }^{11}$ Finally, some companies are concerned that if they offer pension payouts on a phased-retirement basis, they might have trouble passing some of the income-based nondiscrimination tests. ${ }^{12}$

The major concern from a policy perspective is that pension regulations may be forcing an inefficient turnover of workers as they phase into retirement. Inefficiency would emerge if workers switch into jobs where they are less productive and/or incur search costs to make the switch without any offsetting increase in productivity or improvement in the nonpecuniary aspects of the job.

\section{The Transition into Retirement.}

To test the hypothesis that pensions restrain phased retirement, this study uses data from the Health and Retirement Study (HRS). The HRS started in 1992 and surveyed people born between 1931 and 1941 and their spouses. Information was gathered on issues related to health,

\footnotetext{
${ }^{10}$ Under a DC plan, the contributions to a worker's pension account are defined and the retirement benefit depends on the rate of return on the investments.

${ }^{11}$ Kotlikoff and Wise (1989) provide a good discussion of wealth accrual in DB plans and illustrate how pension accrual rates spike at early and normal retirement ages. Accrual rates can also turn negative after a worker becomes eligible for benefits. The logic is that after a worker becomes eligible to collect benefits, pension wealth will increase only if the expected present value of any increment in the annual benefit is sufficient to offset the loss of a year of benefits.ä
${ }^{12}$ According to the Working Group Report on Phased Retirement, passage of nondiscrimination rules could be made difficult by phased retirement because there is a higher concentration of highly compensated employees in the older- age, longer-service categories and there are more highly compensated employees within the particular category of workers whose skills an employer wants to retain by offering phased retirement (e.g., engineers). Consequently, the offer of phased retirement may not be uniform across groups of highly and non-highly compensated employees.


income, retirement and economic status. Wave I of the HRS surveyed 12,652 people in 7,702 households. Additional waves of the survey were completed every two years. Our analysis relies on waves one through four, which were completed in 1992, 1994, 1996 and 1998.

Since we are interested in the transition from full-time work to retirement, we restrict our sample to people between the ages of 50 and 62 who were full-time wage and salary workers in wave I. Throughout this study, workers are defined as full-time if they work 35 or more hours per week for 36 or more weeks per year on their primary jobs. These workers are followed through subsequent waves to track their change in work hours and employers. Since there is some attrition in the sample, people may be included in the panel for anywhere between one and four waves.

Restricting the sample to full-time wage and salary workers between the ages of 50 and 62 in wave I yields 4,423 people in wave I. By wave IV, the sample size drops to 3,440 people. The reduction in sample size results from the fact that the survey may have been unable to obtain an interview from a household in later waves because it was not possible to locate the household, someone died, or the household refused a follow-up interview.

Table 1 gives descriptive statistics for the full-time wage and salary workers included from Wave I. ${ }^{13}$ In Wave I, the average full-time wage and salary worker is 55.2 years old, has 12.8 years of education, works 43.6 hours per week and 51.0 weeks per year, and has been with the current employer for 14.7 years. Men constitute 56.9 percent of the sample. The percentage of workers with pension coverage is 72.5. If broken down by type of pension

\footnotetext{
${ }^{13}$ The wave I sample size drops from 4,770 to 4,744 because observations with missing data on the variables listed in table 1 are dropped from the sample.
} 
coverage, 30.1 percent have only DB coverage; 22.1 percent have only DC coverage; and 20.4 percent have a combination of DB and DC coverage (henceforth denoted as DBDC). ${ }^{14}$

Evidence on the transition from full-time work to retirement is presented in table 2 where the employment status of people who started as full-time wage and salary workers in wave I is tracked in subsequent waves. Among the workers that start as full-time wage and salary workers in wave I, there is a gradual shift to either retirement or part-time work over time. Among those starting as full-time wage and salary workers in wave I, the percentage that are employed in later waves falls from 100 percent in wave I to 66.3 percent by Wave IV. Among those who continue employment across waves, there is a gradual reduction in work hours. Between waves I and IV, the percentage who are full-time workers drops from 100.0 percent in Wave I to 81.2 percent by wave IV.

If pensions impede phased retirement, work hours among those who continue employment should fall at a slower rate for workers who start with pension coverage. To investigate this hypothesis, table 2 provides a breakdown of employment statistics by pension status in wave I. Several points are worth noting. First, workers with DB or DBDC plans are more likely than others to stop working across waves. Workers with DC plans or no pension coverage in wave I are fairly similar in terms of the chance that they stop working over the four waves. The fact that DB and DBDC workers are more likely to stop working across the waves is consistent with the prediction that DB plans encourage earlier retirements than DC plans. ${ }^{15}$

\footnotetext{
${ }^{14}$ Workers classified as having a combination of DB and DC coverage could either have multiple plans with at least one being a DB and at least one being a DC, or a single pension plan that has both DB and DC features.

${ }^{15}$ See, for example, Friedberg and Webb (2000).
} 
Among workers who continue employment across waves, those who start with any type of pension in wave I are less likely to switch from full-time to part-time work. This is consistent with the premise that pensions make it difficult for workers to phase into retirement.

A difficulty with the above results is the fact that pension type in the first wave could be correlated with the worker's age. Consequently, differential changes in work hours across waves could merely reflect differences in worker ages by pension type. To address this issue, table 3 presents employment transitions based upon a worker's age and pension status in the prior wave. For workers who are full-time wage and salary workers in a given wave, transition rates into fulltime employment, part-time employment, and out of the labor force are estimated. ${ }^{16}$ The transition rates are calculated according to the worker's pension status in the first of two consecutive waves.

For all people who were employed as full-time wage and salary workers in a given wave, the fraction who continue as full-time workers diminishes with age while the fraction who switch to part-time work or out of the labor force rises. The percentage continuing in full-time work drops from 88.1 percent among 50-54 year olds to 47.3 percent among workers aged 65 or more. The transition into part-time employment rises from 5.1 percent in the youngest age group to 14.3 percent in the oldest, and the transition to out of the labor force rises from 5.0 to 37.1 percent.

If pensions impede phased retirement, pension coverage should be associated with a lower transition rate to part-time employment. This is precisely what the data suggest. As workers pass from the youngest (50-54) to oldest (65+) age group, the transition rate into part-

\footnotetext{
${ }^{16}$ The three transition rates do not sum to 100 percent because a separate category was added for transition into unemployment. Since the percentage of workers making the transition into unemployment was less than 2 percent for the vast majority of cases, the transition rates into unemployment are not reported for the sake of brevity.
} 
time work rises from 10.4 to 26.4 percent among workers without pension coverage. The transition rate into part-time employment also rises with age for workers with pension coverage, but is much lower than that for workers without pension coverage. For example, in the oldest age group (65+), the part-time transition rate is 6.8 percent for DB workers; 13.8 percent for DC workers; and 11.5 percent for DBDC workers, but 26.4 percent for workers without pension coverage. Hence, consistent with the premise that pensions hinder phased retirement, pension coverage is associated with a lower transition rate into part-time work.

Table 3 also presents transition rates from full-time work to out of the labor force. ${ }^{17}$ These statistics reveal rather stark differences in the transition rates from full-time work to retirement (out of the labor force) across pension status. Workers with DB or DBDC coverage are the most likely to make a transition directly into retirement for workers aged 55 and above. Workers with DC coverage have transition rates into retirement that are fairly similar to workers without any pension coverage. This lends further support to the hypothesis that DC plans are more "age-neutral" in terms of retirement incentives. DB plans on the other hand, tend to encourage retirement (or at least departure from the firm) when the worker reaches early or normal retirement age. ${ }^{18}$

If a worker with pension coverage wants to switch from full-time to part-time work, access to pension assets may be essential to maintaining the same standard of living. Since a switch of employers may be required to access pension assets, workers with pensions should be more likely to switch employers when they make the transition to part-time work. Workers

\footnotetext{
${ }^{17}$ A separate category for transition into unemployment was calculated, but these transition rates were so small that they are excluded from the table for the sake of brevity.

${ }^{18}$ This result is also consistent with Friedberg and Web (2000) who present empirical evidence that switching from DB to $401(\mathrm{k})$ plans will increase the average retirement age by approximately 2 years. 
without pension coverage would not have the same incentive to switch employers. To examine this hypothesis, table 4 presents several additional statistics by lagged pension coverage status. Panel (a) shows that, conditional upon staying with the same employer between consecutive waves, pension covered workers are much less likely to switch from full-time to part-time work. For example, among workers aged 62-64, who continue with the same employer, the percentage who switch to part-time work among those without pension coverage in the prior wave is 15.4 percent. The transition rate to part-time work among pension covered workers is 4.7 for DB coverage; 5.2 for DC coverage; and 7.2 for DBDC coverage. Data on the other age groups support the same conclusion -- pension coverage is associated with a lower chance of switching from full-time to part-time work when the worker continues with the same employer.

If pension coverage makes it difficult to switch to part-time work with the current employer, initial pension coverage should make it more likely that workers switch employers when they switch to part-time work. Panel (b) of table 4 examines this hypothesis with data on the percentage of workers who switch employers when they change from full-time to part-time work. While there are a few exceptions, for nearly every age group, pension covered workers have a higher chance of switching employers than workers without pension coverage when they switch to part-time work.

While pensions might make it more likely that workers switch employers to get access to part-time work, it is frequently argued that pensions (particularly DB plans) penalize quitters and improve employee retention rates. ${ }^{19}$ In the case of DB plans, pension wealth is usually maximized if the worker leaves at either the early or normal retirement age. Consequently, the negative effect of pensions on turnover may diminish as the worker ages. 
In many cases, a switch of employers will result in a pay cut since the value of any firm specific skills is lost. Since workers with pension coverage may have to switch firms to gain access to their pension assets, they may be willing to switch employers even if they experience a cut in pay. Workers without pension coverage, however, have less incentive to switch employers as they phase into retirement. Consequently, workers without pension coverage should be less willing to switch employers if it involves a pay cut.

Data on the median changes in the real wage rate between waves of the HRS in Table 5 affirm the hypothesis that pension covered workers take a larger wage cut when they switch employers. ${ }^{20}$ Among workers who remain with the same employer between waves, the median change in real wages varies between .68 and 1.35 percent across the 4 different pension groupings. This relatively modest wage growth among stayers is in stark contrast to the wage experience of workers who switch employers. The median worker who switches employers experiences a sizable wage cut, particularly if they had a DB or DBDC plan originally. The median percentage point reduction in wages for switchers is 18.4 for DB workers, 24.5 for DBDC, 5.8 for DC and 1.5 for workers without pension coverage. Workers with DB or DBDC coverage realize larger wage cuts than either DC or non-pension workers. If workers only switch employers voluntarily, this suggests the DB and DBDC workers are willing to accept larger pay cuts to facilitate a job switch. Alternatively, if workers switch employers only if forced to do so, DB and DBDC workers are less able to locate employers who will match their

\footnotetext{
${ }^{19}$ For example, see Ippolito (1985) and Ippolito (1991).

${ }^{20}$ Respondents are asked how much their job pays. However, the rate of pay can be reported for various periods of time, e.g., per hour per week, or per year. The hourly wage rate is calculated using measures of usual hours worked per week, usual weeks worked per year, and pay rate, and adjusting appropriately for the periodicity of pay reported.
} 
prior salary, perhaps because they have non-portable skills or are included in a pay contract that either implicitly or explicitly pays in excess of productivity late in the career.

Table 5 also presents data on median change in annual work hours. Consistent with the earlier analysis on transitions to part-time work, workers who stay with their employer between waves experience a zero median change in annual hours worked, regardless of pension status. Among switchers, however, workers with pension coverage (particularly DB or DBDC) reduce hours by a fairly substantial amount. Workers without pension coverage in the prior wave have a zero median change in annual hours. Consequently, among workers who switch employers, prior pension coverage is associated with a larger decrease in work hours.

The analysis thus far has found several patterns in the data that are consistent with the hypothesis that pensions impede the transition from full-time to part-time work as workers approach retirement. First, among full-time workers, the chance that a worker switches to parttime employment in a subsequent wave is lower among workers with pension coverage. Second, among workers that remain with their same employer between waves, pension coverage is associated with a lower chance of switching from full-time to part-time work. Third, among full-time workers who switch employers between waves, workers with pension coverage in the prior period are more likely to make a switch to part-time work Finally, DB and DBDC workers experience larger pay cuts than non-pension workers when they switch employers. Overall, the data are consistent with the premise that pensions are associated with a lower chance of switching from full-time to part-time work without a change in employer, a greater chance that a worker switches employers to accommodate a switch to part-time work, and a larger wage reduction when a worker switches to part-time work. 


\section{Other Impediments to Phased Retirement.}

While the patterns described in the prior section are all consistent with the hypothesis that pensions make it more difficult for workers to phase into retirement without a switch of employers, it is possible that pension coverage is merely proxying for other job characteristics that either cause employers to place greater restrictions on work hours, or make employees less willing to reduce hours. As noted earlier, when a worker is in a job associated with greater quasi-fixed labor costs, the employer will be less willing to allow part-time work because it would increase per hour labor costs unless the worker is willing to take a cut in the hourly wage rate. Inflexible work hours could also emerge when team production is important, or when production technologies leave expensive capital idle when a person works part-time.

Alternatively, employees with pension coverage may have less desire to cut hours if it means they will lose health insurance coverage or other benefits, or if there are large fixed time or money costs associated with working.

To examine whether pension coverage is correlated with other job characteristics that make it less likely that the employer will allow part-time work, we make use of two questions in the HRS. The first asks "Could you reduce the number of hours in your regular work schedule?" $21 \quad$ The second asks "Could you reduce to half-time or less?" Table 6 reports the percentage of full-time wage and salary workers who respond affirmatively to each question. While 35.9 percent of those without a pension report that they could reduce hours, the percentages are much lower for those with pension coverage (17.6 for DB; 25.8 for DC and 19.7 for DBDC). Workers with pension coverage are more likely to be in jobs where the employer 
does not allow a switch to part-time work. The fraction of workers who would be allowed to cut to half-time work illustrates a similar pattern. DB and DBDC workers are one-third as likely as non-pension workers to be allowed to cut to half-time work; DC workers are about one-half as likely.

The fact that employers who provide pension coverage are less willing to allow workers to cut hours suggests that the pension effects observed in the prior section could merely be spurious correlation. Perhaps the pension does not affect worker desires to cut to half-time at all, but workers with pension plans are just more likely to have employers who are reluctant to allow part-time work. This underscores the importance of controlling for other characteristics that might influence either worker desires for part-time work and employer willingness to allow it.

To examine the effect of pension coverage on employment transitions, a multinomial logit model of transition behavior is estimated. The data is restricted to workers who are fulltime wage and salary workers in the first of any two consecutive waves. Depending upon the employment status reported in the second of two consecutive waves, the worker is classified as making a transition from full-time employment to either full-time, part-time, or no employment. In addition to controls for the type of pension in the first of the two-periods, the model controls for employer willingness to allow a reduction to half-time work, the worker's occupation and industry, earnings, education, marital and union status, race, sex, and health insurance coverage, whether the worker has an employed spouse, and the size of the establishment the worker is employed at.

\footnotetext{
${ }^{21}$ The question does not apply to a reduction in overtime hours.
} 
Table 7 provides the estimated effects from the logit model of transition behavior. The estimated marginal probability effect (MPE) for a given variable represents the effect of a one unit change in that variable on the probability of a given outcome. ${ }^{22}$ The MPE for the full-time to full-time transition is omitted since it can be calculated as the sum of MPEs for the two other transitions with the sign reversed.

The empirical model of transition behavior suggests that all three types of pensions (DB, DC, and DBDC) reduce the probability of making a transition from full-time to part-time work, though the effect is statistically insignificant at the .05 level for DBDC plans. Compared to workers without pension coverage, the probability that a worker makes a transition from fulltime to part-time work is 2.0 percentage points lower for workers with DB coverage and 1.5 percentage points lower for workers with DC coverage. While the effect on the transition into part-time work may seem small, only 6.4 percent of workers in the sample make the full-time to part-time transition between waves.

While all three types of pension coverage reduce the probability of making a transition from full-time to part-time work, this is more than offset by the increased probability of making a transition into retirement for DB and DBDC plans. DC plans, on the other hand, reduce the probability of switching to both part-time work and retirement. The fact that DC plans encourage a later retirement than DB plans is consistent with expectations. Pension wealth continues to accumulate in DC plans as long as a worker continues work. In many DB plans, pension wealth will decline if a worker continues working with the same employer beyond the early or normal retirement age.

\footnotetext{
${ }^{22}$ The marginal probability effects are estimated at the sample mean for all explanatory variables. Greene (2003, p. 722) describes how to calculate marginal probability effects and their standard errors using multinomial logit coefficients and the variance-covariance matrix for the coefficients.
} 
Employer willingness to allow a switch to part-time work increases the chance that a worker moves to part-time work and reduces the chance of retiring. Consequently, policies that make it easier for workers to switch to part-time work may mean fewer years of full-time work financed by more years of part-time work.

Consistent with expectations, the chance that a worker makes a switch from full-time to part-time employment rises substantially with age. Workers over age 65 are 5.6 percentage points more likely to switch to part-time work than a worker aged 50-54.

If pensions make it difficult for workers to gradually reduce hours if they stay with the same employer, workers with pensions should be less more likely to switch employers when they switch to part-time work. To investigate this hypothesis, the multinomial logit model of employment transitions is estimated with employment transitions broken into five categories: (1) full-time to full-time with same employer; (2) full-time to full-time with switch of employers; (3) full-time to full-time with same employer; (4) full-time to part-time with switch of employers; and (5) full-time to retirement. The model includes the same controls as in table 7, but the marginal probability effects are presented in table 8 for only a subset of the variables for the sake of brevity.

DB and DC pensions have negative effect on the probability that a worker makes a switch to part-time work with the same employer yet has no statistically significant effect (at the .10 level) on the probability that a worker switches to part-time work with a simultaneous change of employer. This behavior could be explained by restricted access to pension assets making it difficult to switch to part-time work without switching employer.

Not surprisingly, employer willingness to allow a switch to half-time work has a positive effect on the probability that a worker switches to part-time work without a change of employer 
and reduces the chance that a worker switches to retirement. An unexpected result, however, is that employer willingness to allow half-time work also increases the chance that a worker simultaneously switches employers with the change to part-time work. This result might mean that workers who have skills that makes part-time work a viable option to their existing employer find it easier to locate part-time work elsewhere. For example, the production technology that makes it easy for cashiers to switch to part-time work with their current employer may make it easy for cashiers to find part-time work elsewhere.

A shortcoming inherent in these multinomial logit models of employment transitions is that they restrict the effects of all the explanatory variables to be identical across pension types. Since access to pension wealth can increase as a worker ages, pensions may have differential effects on transition probabilities at different points in the life-cycle. To allow for differential effects, multinomial logit models of transition probabilities are estimated separately for workers depending on the type of pension coverage. To summarize the results, the models are then used to simulate employment transitions for each type of pension coverage. It is important to emphasize that the entire population is used to simulate aggregate transition rates for a given type of pension plan. Consequently, differences in the simulated transition rates reflect differences in the effect of pension type alone-- not differences in the types of workers covered by a particular type of pension.

The results of the simulation, summarized in figure 1, reveal that the probability of switching to part-time work without a change of employer rises fairly sharply with age for workers with no pension or DC pensions. Workers with DB pensions, however, do not exhibit this behavior. In fact, for workers with DB pensions, the chance of a switch to part-time work with the same employer is fairly stable as a worker ages. Given that access to assets in some 
DC plans improves when a worker reaches age $59 \frac{1}{2}$, one might expect that DC workers would become more likely to switch to part-time work . With DB plans, however, a worker must switch employers to obtain access. Consequently, worker aging in DB plans would not improve the worker's ability to access pension assets to accommodate their switch to part-time work with the original employer.

The simulation also suggests that the probability of switching employers and reducing to part-time work is fairly similar across pension types until the worker reaches age 65 . When workers pass age 65 , pension coverage is associated with a substantially higher chance of switching employers and reducing to part-time work, though the difference is larger for DB than DC plans. This pattern could be explained by the fact that access to pension assets improves more with worker aging under DC than DB plans.

\section{The Effect of Part-Time Work on Wages.}

Several studies document that part-time work pays a lower hourly wage than full-time work. ${ }^{23}$ Consequently, it is expected that workers who switch to part-time work will experience reductions in their hourly wage. ${ }^{24}$ If workers have firm-specific skills, a switch of employers to accommodate a desired reduction in work hours would reduce wages even further. Consequently, if pension coverage increases the chance that a worker switches employers to

\footnotetext{
${ }^{23}$ See, for example, Blank (1990, 1998), Lettau (1997) and Hirsch (2002).

${ }^{24}$ The rate of pay can be reported for various periods of time, e.g., per hour per week, or per year. The hourly wage rate is calculated using measures of usual hours worked per week, usual weeks worked per year, and the pay rate, and adjusting appropriately for the periodicity of pay reported.
} 
obtain part-time work, pension coverage may increase the size of the wage cut that workers experience when they switch to part-time work.

To determine the effect of a switch to part-time work on hourly wages, we estimate a regression model of the percentage change in the hourly wage rate between waves. Given that the hourly wage must be estimated by dividing annual earnings by annual hours, there is a good deal of noise in our estimate. To help reduce the influence of outliers on the regression estimates, median regression models are employed. The sample includes anyone who was a full-time wage and salary worker in the first of two consecutive waves and continues either parttime or full-time employment in the second wave. The regression includes controls for worker and job characteristics in the first of the two waves. Dummy variables are included to control for a switch of employers or a switch to part-time work. Workers who remain with their original employer as full-time workers are the reference group. Dummies are included for (i) a switch to part-time work without switching employers; (ii) a switch to part-time work with a switch of employers; and (iii) a switch of employers without a switch to part-time work.

Table 9 presents the results of the median wage change regressions. Equations are estimated separately for workers stratified according to their pension status in the first of two consecutive waves of employment. ${ }^{25}$ Using workers who remain with their original employer as full-time workers as the benchmark, a switch to part-time work without switching employers has no statistically significant effect (at the .10 level) on the hourly wage rate regardless of the type of pension coverage. On the other hand, a switch to part-time work with a switch of employers has a statistically significant negative effect for workers in any pension coverage category, but the effects are much larger for those this with prior pension coverage than for those without. A

\footnotetext{
${ }^{25}$ Standard errors are calculated with bootstrap methods using 500 draws.
} 
switch to part-time work with a switch of employers reduces wages by over 30 percentage points for workers with pension coverage. For workers without pension coverage, the effect is 13 percentage point wage reduction. The fact that pension covered workers realize a larger wage cut when they switch employers as they cut back to part-time work is consistent with the premise that pension covered workers are more willing to absorb a wage cut associated with a switch of employers because it provides them access to pension wealth. Alternatively, it is possible that pension covered workers are more likely to experience large wage cuts when they switch employers because they have more firm specific skills. An obvious question is why they would switch employers if it leads to such a large wage cut.

\section{Summary and Conclusions.}

This study has investigated the hypothesis that pension coverage may make it difficult for workers to gradually phase into retirement by reducing hours worked. The premise is that restrictions on worker access to pension wealth without a switch of employers could make it difficult for the worker to finance a switch to part-time work. Workers with pension coverage who wish to switch to part-time work may have to switch employers in order to access pension wealth.

Analysis of data in the first four waves of the HRS lends support for numerous hypotheses that are consistent with the notion that pensions impede phased retirement. First, pension covered workers are less likely to switch to part-time employment as they approach retirement age, but are more likely to switch directly from full-time work to no work. This result holds even after controlling for the original employer's willingness to allow a reduction in work hours and numerous firm and worker characteristics. Second, when workers switch to 
part-time work, those with pension coverage are more likely to make a switch of employers in the process.

While pension coverage reduces the chance that a worker switches to part-time employment, there is strong evidence that numerous other factors play an important role. Perhaps most importantly, nearly two-thirds of workers indicate their employers are unwilling to allow workers to switch to part-time work. Our evidence suggests that if employers were more flexible in allowing reduced work hours, workers would be more likely to switch to part-time employment and retire at a later date.

Even after controlling for whether the employer would allow workers to switch to parttime work, pension coverage impacts the chance of such a switch. Pension coverage also increases the chance that a worker switches to part-time work if there is change of employers. Finally, while pension coverage reduces the chance that workers switch employers when they are in their 50s, the effect disappears when they are in their $60 \mathrm{~s}$. All of these patterns support the hypothesis that pensions reduce the chance of switching to part-time work, but increase the chance that a worker switches employers to make a switch to part-time work.

The empirical analysis also reveals that that workers take substantial wage cuts when they switch to part-time work, but only if the switch is simultaneous to a switch of employers. While workers with and without pension coverage both take substantial wage cuts when they switch employers and move to part-time work, the wage cuts are much larger for pension covered workers. This is consistent with the hypothesis that pension covered workers are more willing to make a job change that involves a wage cut because of the importance of accessing pension wealth. 


\section{References}

Allen, Steven G; Clark, Robert L.; and Ghent, Linda S. "Phasing into Retirement," National Bureau of Economic Research Working Paper Number 9779, June 2003.

Blank, Rebecca M. “Are Part-time Jobs Bad Jobs?” In A Future of Lousy Jobs? The Changing Structure of U.S. Wages, edited by Gary Burtless. Washington, D.C.: The Brookings Institution, 1990.

. "Labor Market Dynamics and Part-Time Work." Research in Labor Economics 17 (1998): 57-93.

Fallick, Bruce. "Part-time Work and Industry Growth." Monthly Labor Review 122 (March 1999): 22-29.

Fields, Vivian and Hutchens, Robert. "Regulatory Obstacles to Phased Retirement in the ForProfit Sector." Benefits Quarterly 18 (Quarter 3): 35-41.

Friedberg, Leora, and Webb, Anthony, "Retirement and the Evolution of Pension Structure" University of California-San Diego Working Paper No. 2000-30, November 2000.

Graig, Laurene, and Paganell, Valerie. "Phased Retirement: Reshaping the End of Work." Compensation and Benefits Management 16 (Spring 2000): 1-9.

Greene, William E. Econometric Analysis, 5th Edition. Upper Saddle River, NJ: Prentice Hall, 2003.

Gustman, Alan and Steinmeier, Thomas. "Partial Retirement and the Analysis of Retirement Behavior." Industrial and Labor Relations Review 37 (April 1984): 403-15.

Hirsch, Barry T. "Why Do Part-Time Workers Earn Less? The Role of Worker and Job Skills." Industrial and Labor Relations Review, forthcoming.

Honig, Marjorie. "Partial Retirement among Women” Journal of Human Resources 20 (Fall 1985): 613-21.

Honig, Majorie and Giora Hanoch. "Partial Retirement as a Separate Mode of Retirement Behavior." Journal of Human Resources 20 (Winter 1985): 21-46.

Ippolito, Richard A. "The Labor Contract and True Economic Pension Liabilities.” American Economic Review 75 (December 1985): 1031-1043. . "Encouraging Long Term Tenure: Wage Tilt or Pensions?" Industrial \& Labor Relations Review 44 (April 1991): 520-535.

Kotlikoff, Laurence J. and David Wise. The Wage Carrot and the Pension Stick: Retirement Benefits and Labor Force Participation. Kalamazoo, Mich.: W. E. Upjohn Institute, 1989. 
Latulippe, Denis, and Turner, John. "Partial Retirement and Pension Policy in Industrialized Countries." International Labour Review 139 (Number 2, 2000): 179-195.

Lettau, Michael K. "Compensation in Part-Time Versus Full-Time Jobs: What if the Job is the Same?” Economic Letters 56 (September 1997): 101-06.

Montgomery, Mark, and Cosgrove, James. "The Effect of Employee Benefits on the Demand for Part-time Workers." Industrial and Labor Relations Review 47 (October 1993): 87-98.

Oi, Walter. "Labor as a Quasi-Fixed Factor." Journal of Political Economy 70 (December 1962): 538-555.

Purcell, Patrick. "Older Workers: Employment and Retirement Trends." Congressional Research Service Report, September 2004.

Quinn, Joseph. "New Paths to Retirement," In Forecasting Retirement Needs and Retirement Wealth, edited by Olivia S. Mitchell, P. Brett Hammond, and Anna M. Rappaport.

Philadelphia : University of Pennsylvania Press, 2000.

Ruhm, Christopher J. "Bridge Jobs and Partial Retirement." Journal of Labor Economics 8 (October 1990): 482-501.

Watson-Wyatt. Current Practices in Phased Retirement: Transforming the End of Work. People Management Resources, Watson Wyatt Worldwide, 2000.

Working Group Report on Phased Retirement, submitted to the ERISA Advisory Council, November 2000. 
Table 1. Sample Means for Wave I of Health and Retirement Survey.

Variable

Age

Male

Years of Education

Years of Tenure

Hours worked per week

Weeks Worked Per Year

Covered by a Pension

Covered by only a DB Pension

Covered by only a DC Pension

Covered by a DB and a DC Pension

Sample Size
Average

55.2

$56.9 \%$

12.8

14.7

43.6

51.0

$72.5 \%$

$30.1 \%$

$22.1 \%$

$20.4 \%$

4423

Note: The data source is the 1992 Health and Retirement Study. The sample is restricted to fulltime wage and salary workers aged 50 to 62 . 
Table 2. Employment Status and Distribution of Hours and Weeks by Type of Pension Coverage in Wave 1.

\begin{tabular}{|c|c|c|c|c|c|}
\hline Wave & Only DB & Only DC & Both DB and DC & No pension & All \\
\hline \multicolumn{6}{|c|}{$\underline{\text { Percent Employed }}$} \\
\hline 1 & $100.0 \%$ & $100.0 \%$ & $100.0 \%$ & $100.0 \%$ & $100.0 \%$ \\
\hline 2 & $85.9 \%$ & $89.1 \%$ & $88.3 \%$ & $86.5 \%$ & $87.3 \%$ \\
\hline 3 & $74.5 \%$ & $81.3 \%$ & $75.7 \%$ & $77.2 \%$ & $77.0 \%$ \\
\hline 4 & $62.3 \%$ & $71.9 \%$ & $61.3 \%$ & $70.3 \%$ & $66.3 \%$ \\
\hline Change between & $-37.7 \%$ & $-28.1 \%$ & $-38.7 \%$ & $-29.7 \%$ & $-33.7 \%$ \\
\hline \multicolumn{6}{|c|}{ Among Employed, Percent Full time } \\
\hline 1 & $100.0 \%$ & $100.0 \%$ & $100.0 \%$ & $100.0 \%$ & $100.0 \%$ \\
\hline 2 & $95.1 \%$ & $94.1 \%$ & $96.3 \%$ & $87.2 \%$ & $93.0 \%$ \\
\hline 3 & $88.6 \%$ & $90.1 \%$ & $88.8 \%$ & $82.5 \%$ & $87.4 \%$ \\
\hline 4 & $83.1 \%$ & $82.6 \%$ & $83.4 \%$ & $76.7 \%$ & $81.2 \%$ \\
\hline $\begin{array}{c}\text { Change between } \\
\text { waves } 1 \text { and } 4\end{array}$ & $-16.9 \%$ & $-17.4 \%$ & $-16.6 \%$ & $-23.3 \%$ & $-18.8 \%$ \\
\hline Sample Size & 4,447 & 4,057 & 3,734 & 3,440 & 15,678 \\
\hline
\end{tabular}

Note: The sample is drawn from Waves 1 through 4 of the HRS with the sample restricted to people who were full-time wage and salary workers aged 50 to 62 in Wave 1. 
Table 3. Transitions from Full-time Wage and Salary Employment by Pension Type in Prior Wave.

\begin{tabular}{|c|c|c|c|c|c|}
\hline Age Group & Only DB & Only DC & Both DB and DC & No Pension & All \\
\hline \multicolumn{6}{|c|}{ Full-time to Full-Time } \\
\hline $50-54$ & $88.7 \%$ & $91.0 \%$ & $92.5 \%$ & $80.5 \%$ & $88.1 \%$ \\
\hline $55-59$ & $83.9 \%$ & $88.6 \%$ & $87.3 \%$ & $80.6 \%$ & $84.8 \%$ \\
\hline $60-61$ & $74.1 \%$ & $84.3 \%$ & $79.1 \%$ & $78.4 \%$ & $78.6 \%$ \\
\hline $62-64$ & $53.3 \%$ & $60.5 \%$ & $61.3 \%$ & $61.4 \%$ & $58.4 \%$ \\
\hline $65+$ & $44.3 \%$ & $56.3 \%$ & $39.5 \%$ & $44.6 \%$ & $47.3 \%$ \\
\hline \multicolumn{6}{|c|}{ Full-Time to Part-Time } \\
\hline $50-54$ & $4.1 \%$ & $4.2 \%$ & $1.9 \%$ & $10.4 \%$ & $5.1 \%$ \\
\hline $55-59$ & $4.2 \%$ & $4.7 \%$ & $3.0 \%$ & $8.0 \%$ & $5.0 \%$ \\
\hline $60-61$ & $5.1 \%$ & $6.1 \%$ & $6.1 \%$ & $9.4 \%$ & $6.6 \%$ \\
\hline $62-64$ & $8.5 \%$ & $8.6 \%$ & $6.8 \%$ & $14.7 \%$ & $9.9 \%$ \\
\hline $65+$ & $6.8 \%$ & $13.8 \%$ & $11.5 \%$ & $26.4 \%$ & $14.3 \%$ \\
\hline \multicolumn{6}{|c|}{ Full-Time to Out of Labor Force } \\
\hline $50-54$ & $5.2 \%$ & $3.5 \%$ & $4.9 \%$ & $6.1 \%$ & $5.0 \%$ \\
\hline $55-59$ & $10.8 \%$ & $5.2 \%$ & $9.0 \%$ & $8.9 \%$ & $8.7 \%$ \\
\hline $60-61$ & $19.7 \%$ & $8.4 \%$ & $13.6 \%$ & $8.2 \%$ & $12.9 \%$ \\
\hline $62-64$ & $37.6 \%$ & $27.9 \%$ & $31.3 \%$ & $22.4 \%$ & $30.2 \%$ \\
\hline $65+$ & $47.2 \%$ & $29.9 \%$ & $49.0 \%$ & $26.4 \%$ & $37.1 \%$ \\
\hline Sample Size & 3,164 & 2,147 & 1,453 & 2,334 & 9,098 \\
\hline
\end{tabular}

Note: The sample is drawn from HRS waves 1 through 4 . The transition rates are calculated using people who are full-time wage and salary workers in the first of two consecutive waves of the HRS and between the ages of 50 and 62 in wave 1. 
Table 4. Full-time to Part-time Transitions by Pension Type in Prior Wave.

\begin{tabular}{|c|c|c|c|c|c|}
\hline Age Group & Only DB & Only DC & $\begin{array}{c}\text { Both DB and } \\
\text { DC }\end{array}$ & No Pension & All \\
\hline \multicolumn{6}{|c|}{ (a) Among Stayers, $\%$ Switching Full-time to Part-Time } \\
\hline $50-54$ & $2.2 \%$ & $4.4 \%$ & $1.3 \%$ & $9.2 \%$ & $3.9 \%$ \\
\hline $55-59$ & $2.2 \%$ & $2.7 \%$ & $1.1 \%$ & $5.3 \%$ & $2.7 \%$ \\
\hline $60-61$ & $2.2 \%$ & $3.4 \%$ & $2.4 \%$ & $5.8 \%$ & $3.5 \%$ \\
\hline $62-64$ & $4.7 \%$ & $5.2 \%$ & $7.2 \%$ & $15.4 \%$ & $8.3 \%$ \\
\hline $65+$ & $4.5 \%$ & $10.3 \%$ & $0.0 \%$ & $32.2 \%$ & $14.3 \%$ \\
\hline \multicolumn{6}{|c|}{ (b) Among Those Switching from Full-Time to Part-Time, Percent Switching Employers } \\
\hline $50-54$ & $54.5 \%$ & $11.3 \%$ & $36.2 \%$ & $39.2 \%$ & $37.8 \%$ \\
\hline $55-59$ & $58.0 \%$ & $53.2 \%$ & $71.2 \%$ & $54.2 \%$ & $56.9 \%$ \\
\hline $60-61$ & $67.8 \%$ & $53.7 \%$ & $69.7 \%$ & $54.7 \%$ & $60.0 \%$ \\
\hline $62-64$ & $70.4 \%$ & $64.8 \%$ & $34.2 \%$ & $32.1 \%$ & $50.7 \%$ \\
\hline $65+$ & $70.7 \%$ & $54.9 \%$ & $100.0 \%$ & $26.3 \%$ & $47.1 \%$ \\
\hline Sample Size & 3,164 & 2,147 & 1,453 & 2,334 & 9,098 \\
\hline
\end{tabular}

Note: The sample is drawn from HRS waves 1 through 4 . The statistics are calculated using people who are full-time wage and salary workers in the first of two consecutive waves of the HRS and between the ages of 50 and 62 in wave 1 . 
Table 5. Median Changes in Hourly Wage for Stayers and Switchers.

\begin{tabular}{ccc}
\hline $\begin{array}{c}\text { Median Change in } \\
\text { Hourly Wage }\end{array}$ & $\begin{array}{c}\text { Median Change in } \\
\text { Annual Hours }\end{array}$ & Sample Size \\
\hline
\end{tabular}

Only DB

Workers Who Stay with Same Employer

Only DC

$0.68 \%$

$1.21 \%$

$0.78 \%$

$1.35 \%$

0

0

2,357

1,668

Both DB and DC

1,164

1,585

Workers Who Switch to Different Employer

$\begin{array}{lccc}\text { Only DB } & -18.39 \% & -416 & 182 \\ \text { Only DC } & -5.79 \% & -120 & 192 \\ \text { Both DB and DC } & -24.47 \% & -416 & 81 \\ \text { No Pension } & -1.51 \% & 0 & 407\end{array}$

Note: Sample includes people from HRS waves 1 through 4 who were full-time wage and salary workers in the first of two consecutive waves and continued employment in the subsequent wave. 
Table 6. Employer Willingness to Allow Reduced Work Hours.

\begin{tabular}{lcccc}
\hline & $\begin{array}{c}\text { Percentage of } \\
\text { workers that } \\
\text { could reduce } \\
\text { hours }\end{array}$ & Sample Size & $\begin{array}{c}\text { Percentage of } \\
\text { workers that } \\
\text { could reduce } \\
\text { hours to half or } \\
\text { less }\end{array}$ & Sample Size \\
\hline Only DB & $17.6 \%$ & 3,874 & $6.9 \%$ & 3,844 \\
Only DC & $25.8 \%$ & 2,696 & $11.6 \%$ & 2,665 \\
Both DB and DC & $19.7 \%$ & 1,740 & $6.2 \%$ & 1,728 \\
No Pension & $35.9 \%$ & 2,915 & $20.3 \%$ & 2,864 \\
\hline
\end{tabular}

Note: Sample restricted to full-time wage and salary workers from Waves 1 through 4 of HRS. 
Table 7. Multinomial Logit Model of Employment Transitions.

\begin{tabular}{|c|c|c|c|c|}
\hline \multirow[b]{3}{*}{ DR nlan (No Pension omitted) } & \multicolumn{2}{|c|}{ Full-time to part-time } & \multicolumn{2}{|c|}{ Full-time to retirement } \\
\hline & MPE & t-statistic & MPE & t-statistic \\
\hline & -0.020 & -3.31 & 0.032 & 3.74 \\
\hline DC plan & -0.015 & -2.45 & -0.015 & -1.56 \\
\hline DB DC plan & -0.016 & -1.24 & 0.023 & 1.37 \\
\hline Employer allows half-time work & 0.032 & 5.41 & -0.021 & -1.71 \\
\hline Tenure & 0.000 & 0.46 & 0.003 & 7.79 \\
\hline Real Annual Earnings (in \$100k) & 0.000 & -2.32 & 0.000 & -2.87 \\
\hline \multicolumn{5}{|l|}{ Real Annual Earnings (in $\$ 100 \mathrm{k}$ ) } \\
\hline Squared & 0.000 & 3.30 & 0.000 & 2.72 \\
\hline \multicolumn{5}{|l|}{ Age } \\
\hline 55 to 59 & 0.015 & 2.59 & 0.034 & 3.85 \\
\hline 60 to 61 & 0.045 & 6.20 & 0.167 & 17.20 \\
\hline 62 to 64 & 0.057 & 6.39 & 0.186 & 15.13 \\
\hline 65 and over & 0.056 & 1.84 & 0.185 & 4.46 \\
\hline \multicolumn{5}{|l|}{ Years of education } \\
\hline 12 & 0.001 & 0.19 & -0.024 & -2.55 \\
\hline $13-15$ & 0.005 & 0.57 & -0.024 & -2.03 \\
\hline 16 & 0.000 & -0.03 & -0.019 & -1.37 \\
\hline Plant Size 25 to 99 & 0.004 & 0.63 & -0.015 & -1.52 \\
\hline Plant Size 100 to 499 & -0.011 & -1.60 & -0.013 & -1.25 \\
\hline Plant Size 500+ & -0.016 & -2.14 & 0.006 & 0.55 \\
\hline Union coverage & 0.004 & 0.60 & 0.009 & 1.16 \\
\hline \multicolumn{5}{|l|}{$\begin{array}{l}\text { Marital status (previously married } \\
\text { omitted) }\end{array}$} \\
\hline Married & 0.011 & 1.70 & -0.007 & -0.74 \\
\hline Never Married & -0.038 & -2.05 & 0.004 & 0.22 \\
\hline \multicolumn{5}{|l|}{ Race (white omitted } \\
\hline Black & -0.006 & -0.78 & 0.000 & 0.08 \\
\hline Other & -0.017 & -1.15 & -0.016 & -0.81 \\
\hline Male & -0.003 & -0.45 & -0.029 & -3.16 \\
\hline Percent of sample making transition & 6.4 & & 13.7 & \\
\hline Sample size & 8,764 & & & \\
\hline
\end{tabular}

Note: The marginal probability effect (MPE) is the estimated effect of a one unit change in the explanatory variable on the probability of a given type of transition. The omitted transition is from full-time employment to full-time employment. The model also includes controls for 13 industries and 17 occupations. 
Table 8. Multinomial Logit Model of Employment Transitions Including Switch of Employers.

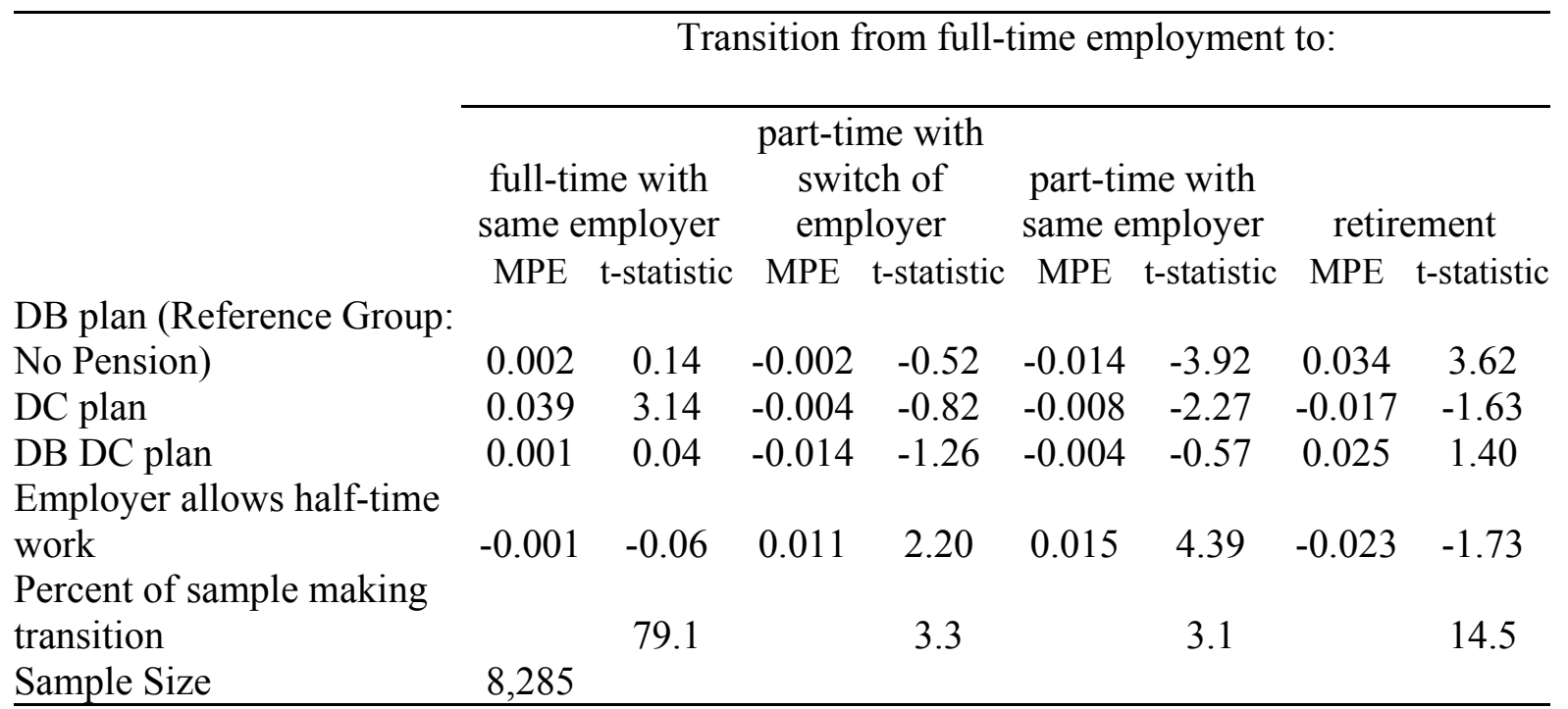

Notes: The marginal probability effect (MPE) is the estimated effect of a one unit change in the explanatory variable on the probability of a given type of transition. The omitted transition is from full-time employment to full-time employment. Models also include controls for all variables listed in table 7. 
$m$

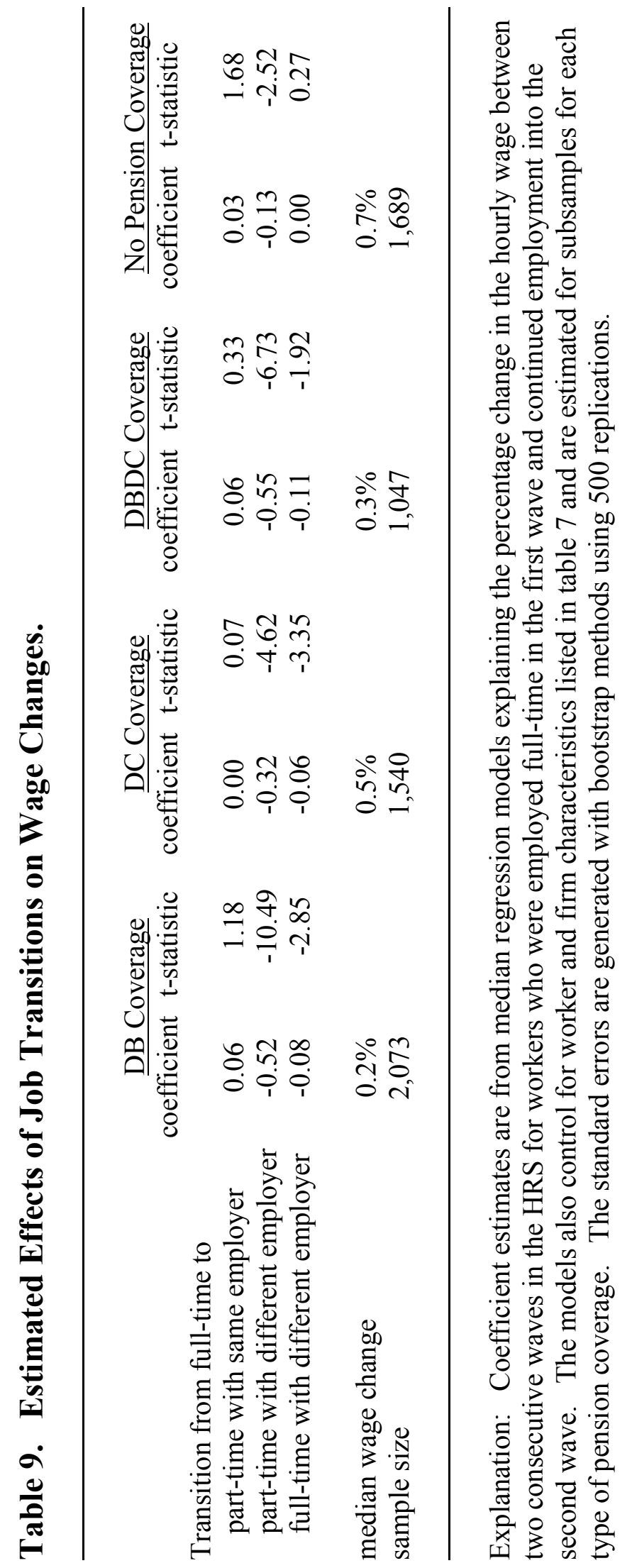




\section{Figure 1. The Effect of Pensions on the Transition from Full-Time Employment}

Explanation: The figures present estimates of the average probability that a full-time wage and salary worker makes a transition into one of 5 possible work states between consecutive waves of the HRS. The estimates are derived from multinomial logit models of transition probabilities estimated for sub-samples of the HRS based upon their pension status as a full-time wage and salary worker. Since the entire sample of full-time wage and salary workers is used to generate the average transition probability for each pension type, the differences in transition probabilities across pension type reflect only the effect of the pension. The age groupings are based on the worker age in the first of the two consecutive waves.
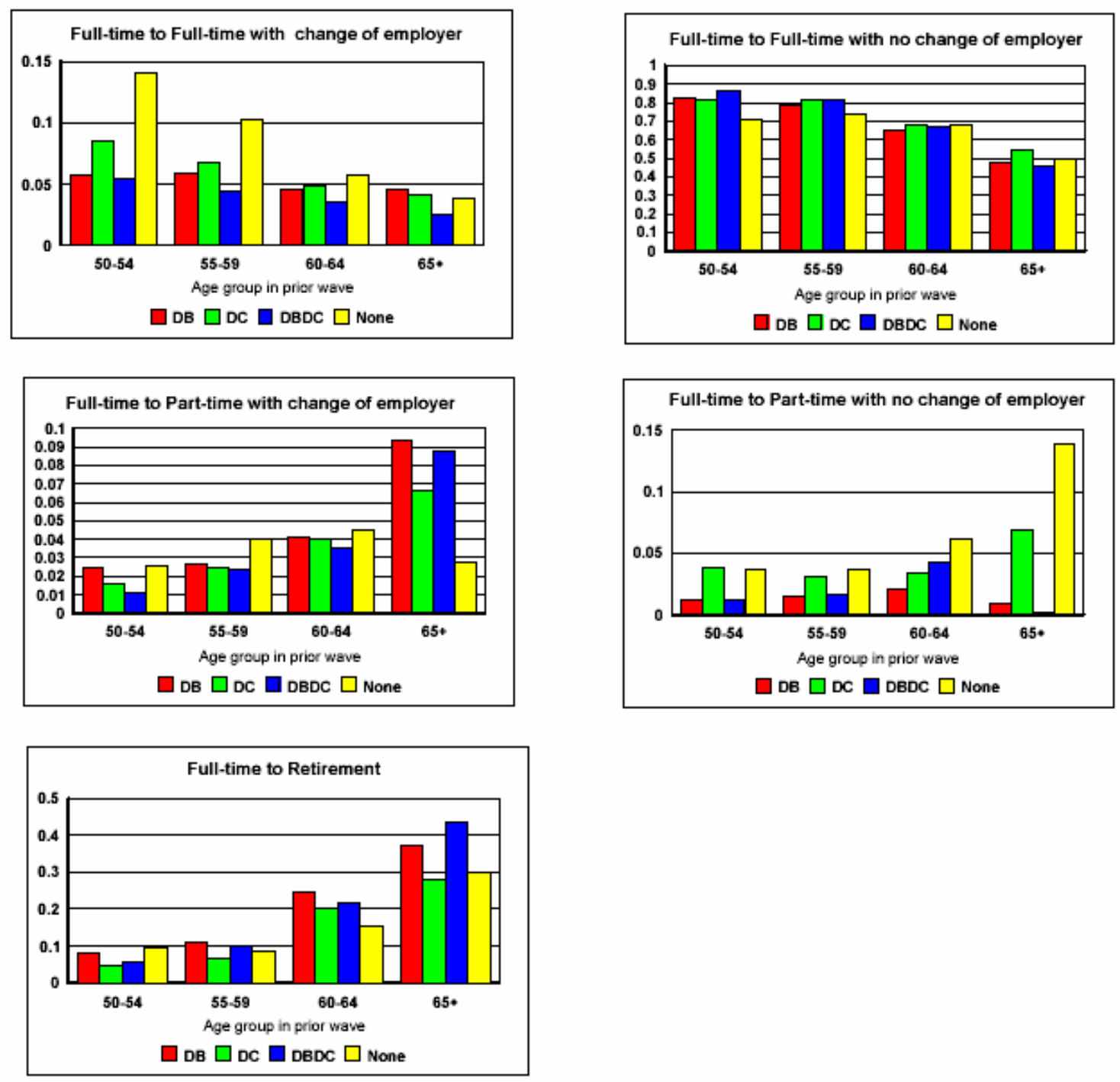